\title{
PERANCANGAN E-COMMERCE PADA PT. ADTRONIC INDONESIA
}

\author{
Aris Hermawan ${ }^{1}$ \\ Program Studi Sistem \\ Informasi \\ STMIK Nusa Mandiri Jakarta \\ arishermawan@hotmail.com
}

\author{
Titin Kristiana ${ }^{2}$ \\ Program Studi Sistem \\ Informasi \\ STMIK Nusa Mandiri Jakarta \\ titin.tka@nusamandiri.ac.id
}

\author{
Eka Satryawati ${ }^{3}$ \\ Program Studi Sistem \\ Informasi \\ Universitas MH Thamrin \\ ekathufail@gmail.com
}

\begin{abstract}
Abstrak
PT. Adtronic Indonesia adalah perusahaan bergerak dibidang industri dan perdagangan elektronik, produk-produk yang dijual oleh perusahaan ini berkaitan dengan media periklanan dan penerangan umum, produk-produk yang dijual antara lain : LED Lamp, LED Display, dan Decoration Lamp. LED terdapat berbagai fungsi dapat sebagai desain interior, media periklanan dan juga dapat menghemat energi hingga $75 \%$, selain itu produk ini memiliki fasilitas plug and play sehingga pelanggan dapat dengan mudah menginstalasi dan mengoperasikan produk ini. Kini banyak pihak lain (pesaing) memproduksi dan menjual produk ini. Walaupun sebenarnya dari segi kualitas tetap unggul karena perusahaan ini bekerjasama langsung dengan Seoul Semiconductor, namun tetap saja pelanggan dan publik tidak mengetahui informasi ini secara langsung, untuk mendapatkan informasi dan memesan produk pelanggan dapat mengirim email atau menghubungi bagian layanan pelanggan. E-Commerce (penjualan online) adalah fasilitas untuk memberikan informasi mengenai produk terhadap publik dan sebagai media promosi dalam bentuk aplikasi dengan cakupan yang sangat luas, e-commerce dapat diakses dimana saja dan kapan saja, dengan begitu pelanggan pun dapat mendapatkan informasi dengan mudah.
\end{abstract}

\section{Kata kunci : E-Commerce, LED, Penerangan}

\section{PENDAHULUAN}

PT. Adtronic Indonesia adalah perusahaan bergerak dibidang industri dan perdagangan elektronik, produk-produk yang dijual oleh perusahaan ini berkaitan dengan media periklanan dan penerangan umum. Produk-produk yang dijual antara lain : LED Lamp, LED Display, dan Decoration Lamp.

LED terdapat berbagai fungsi dapat sebagai desain interior, media periklanan dan juga dapat menghemat energi hingga $75 \%$, selain itu produk ini memiliki fasilitas plug and play sehingga pelanggan dapat dengan mudah menginstalasi dan mengoperasikan produk ini.

Saat ini PT. Adtronic Indonesia mempunyai sebuah website company profile sebagai fasilitas untuk memberikan informasi produk kepada publik, namun website tersebut hanya menampilkan informasi secara umum, belum ada informasi mengenai harga dan spesifikasi produk secara khusus, sehingga tetap saja pelanggan harus menghubungi Langsung pihak PT. Adtronic Indonesia, Kendala di perusahaan ini adalah sedikitnya personil yang menangani bagian layanan pelanggan dan menerima pesanan, sehingga pelanggan kesulitan medapat informasi mengenai produk. Selain itu kendala yang ada diperusahaan ini adalah bertempat di lokasi yang kurang strategis, yang berakibat sulit terjangkau oleh pelanggan.

E-Commerce (penjualan online) adalah fasilitas untuk memberikan informasi mengenai produk terhadap publik dan sebagai media promosi dalam bentuk aplikasi dengan cakupan yang sangat luas, e-commerce dapat diakses dimana saja dan kapan saja, dengan begitu pelanggan pun dapat mendapatkan informasi dengan mudah.

Menurut Handita dkk (2012:26-27) : Perusahaan yang ingin meningkatkan penjualan tidak dapat melepaskan diri dari kegiatan pemasaran. Pemasaran yang baik dan yang tersebar luas merupakan faktor untuk meningkatkan hasil penjualan perusahaan. Cara manual menyebabkan sistem yang sedang berjalan tidak seefektif dan seefisien yang diharapkan serta pelanggan-pelanggan yang di daerah tidak dapat dijangkau dengan baik oleh perusahaan. Untuk mengendalikan masalah ini, maka perlu dirancang program aplikasi pemasaran dan penjualan yang berbentuk website yang digunakan untuk pemasaran dan proses penjualan secara online.

Berdasarkan beberapa hal diatas maka penulis mencoba melakukan suatu penelitian dan implementasi di PT. Adtronic Indonesia pada 
bagian pemesanan barang dalam hal ini $E$ Commerce. Dengan E-Commerce diharapkan para pelanggan dapat memesan produk secara langsung secara bersamaan dan dapat mendapatkan informasi produk yang akan dibeli melalui halaman website.

\section{KAJIAN LITERATUR}

\subsection{Pengertian Sistem Informasi}

Menurut Robert A. Leitch dan K. Roscoe Davis dalam Jogiyanto (2005:11) mengemukakan bahwa "Sistem informasi adalah suatu sistem di dalam suatu organisasi yang mempertemukan kebutuhan pengolahan transaksi harian, mendukung operasi, bersifat manajerial dan kegiatan strategi dari suatu organisasi dan menyediakan pihak luar tertentu dengan laporanlaporan yang diperlukan."

\subsection{Waterfall Model}

Menurut Pressman (2010:39), model waterfall adalah "model klasik yang bersifat sistematis, berurutan dalam membangun software". Nama model ini sebenarnya adalah "Linear Sequential Model".

\subsection{Black-Box Testing}

Menurut Pressman (2010:495) "Black-Box testing berfokus pada persyaratan fungsional perangkat lunak yang memungkinkan engineers untuk memperoleh set kondisi input yang sepenuhnya akan melaksanakan persyaratan fungsional untuk sebuah program".

\subsection{Unified Modelling Languange (UML)}

Menurut Nugroho (2010:6) "UML (Unified Modeling Language) adalah bahasa pemodelan untuk sistem atau perangkat lunak yang berparadigma (berorientasi objek)".

\subsection{Entity Relationship Diagram (ERD)}

Entity relationship (ER) data model didasarkan pada persepsi terhadap dunia nyata yang tersusun atas kumpulan objek-objek dasar yang disebut entitas dan hubungan antar objek. Menurut Simamarta dan Prayudi (2006:67) "Entity Relationship Diagram adalah alat permodelan data utama dan akan membantu mengorganisasi data dalam suatu proyek ke dalam entitas-entitas dan menentukan hubungan antarentitas".

\subsection{Database Management System (DBMS)}

Menurut Sukamto dan Shalahuddin (2013:43) "DBMS (Database Management System) atau Sistem Manajemen Basis data adalah suatu sistem aplikasi yang digunakan untuk menyimpan dan menampilkan data".

\subsection{Hypertext PreProcessor (PHP)}

Menurut Doyle (2010:3) menjelaskan bahwa : PHP (Hypertext PreProcessor) adalah bahasa pemrograman yang dirancang untuk membangun web yang bisa menghasilkan halaman web yang dinamis dan juga interaktif. Program PHP dijalankan di web server, dan melayani halaman web setiap ada request yang berasal dari pengunjung.

\subsection{Object Oriented Programming (OOP)}

Menurut Sakur (2010:178) "Pemrograman berorientasi objek adalah sebuah teknik pemrograman yang dalam proses pengembangannya menggunakan terminologi objek, dimana setiap objek memiliki atribut beserta dengan fungsi yang dapat saling berinteraksi satu dengan yang lain seperti halnya objek."

\subsection{Konsep Model View Controller (MVC)}

Menurut Sidik (2012:29) "MVC (Model View Controller) merupakan teknik pemrograman yang mengharapkan pemogram secara disiplin untuk membagi program menjadi 3 bagian : model, view dan controller".

\subsection{E-Commerce}

E-Commerce atau yang sering juga disebut dengan Internet Commerce pada dasarnya mempunyai makna yang sama yang berarti seseorang konsumen untuk dapat membeli barang yang diinginkan secara online melalui jaringan internet.

Menurut Nurgoho (2006:5) "E-commerce didefinisikan sebagai cara untuk menjual dan membeli barang-barang (dan jasa) lewat jaringan internet".

E-Commerce secara umum merupakan kegiatan bisnis perniagaan maupun perdagangan atau jasa yang berhubungan erat dengan konsumen (consumers), manufaktur, internet service provider (ISP) dan pedagang perantara (intermediateries) dengan menggunakan media electronic. Dalam hal ini media electronic utamanya adalah internet.

\section{METODE PENELITIAN}


Metode atau teknik yang digunakan adalah menggunakan metode :

A. Metode Pengamatan (Observation)

Penulis melakukan pengamatan-pengamatan langsung terhadap kegiatan yang berhubungan dengan masalah yang diambil. Hasil dari pengamatan tersebut langsung dicatat oleh penulis dan dari kegiatan observasi dapat diketahui kesalahan atau proses dari kegiatan tersebut. Hal ini dilakukan untuk memperkuat data yang diperoleh pada saat wawancara di PT. Adtronic Indonesia.

B. Metode Wawancara (Interview)

Penelitian yang dilakukan untuk memperoleh informasi dengan cara tatap muka. Dalam penelitian ini penulis mengadakan wawancara langsung dengan Bapak Nasril bagian Penjualan untuk mendapatkan informasi mengenai proses pemesanan dan penjualan produk.

\section{Studi Pustaka}

Dalam metode ini penulis mengambil semua bentuk karangan buku-buku, jurnal, dan media internet yang berhubungan dalam penelitian ini untuk mempelajari data yang telah dirangkum.

Dalam mengembangkan sistem, akan digunakan metode waterfall dan menggunakan UML sebagai standar pemodelannya. Metode pengembangan sistem dilakukan secara waterfall karena merupakan metode yang tepat.Tahapan metode ini diantaranya:

\section{A. Analisa Kebutuhan Sistem}

Pada tahap ini penulis melakukan analisa tentang kebutuhan pengguna dan pelanggan dalam rangka meningkatkan efektifitas dalam pemesanan dan penjualan produk.

\section{B. Desain}

Penulis menggunakan permodelan untuk menggambarkan sistem, untuk rancangan database penulis menggunakan Data Model dan pembuatan software architecture pada tahapan ini menggambarkan use case diagram, activity diagram, class diagram, sequence diagram, component diagram, dan deployment diagram, sedangkan untuk interface dengan menampilkan form-form pada program e-commerce.

\section{Code Generation}

Code Generation adalah proses dimana compiler generator code mengkonversi kode sumber menjadi bentuk yang didapat dengan mudah dieksekusi mesin. Pada tahap ini penulis merancang program dengn konsep MVC (Model, View, Controller) dengan menggunakan framework dan termasuk dalam program berorientasi objek (Object Oriented Programming) .

D. Testing

Pada tahap ini penulis akan melakukan testing / pengujian terhadap program dibuat dengan menggunakan teknik pengujian black box, dimana pada pengujian ini hanya dapat diketahui outputnya saja tanpa pengetahuan detil struktur internal dari sistem atau komponen yang dites.

\section{E. Support}

Pada tahap ini penulis menganalisa dukungan yang menunjang untuk merancang sistem ini tentang spesifikasi perangkat yang digunakan. Yaitu dengan tersedianya server dalam hal ini penyimpanan online dan domain untuk dapat diakses oleh publik.

\section{HASIL DAN PEMBAHASAN}

\subsection{Analisa Sistem Berjalan}

Konsumen menghubungi Bagian Penjualan melalui email atau telepon untuk meminta spesifikasi dan harga barang yang akan dibeli, kemudian bagian Penjualan melakukan pengecekan stok, jika tersedia maka membuat dokumen penawaran harga yang selanjutnya dikirim kepada Konsumen, jika Konsumen menyetujui penawaran harga maka Konsumen melakukan pemesanan barang dengan konfirmasi melalui email dengan menyertakan dokumen PO (Purchase Order) atau mengkonfirmasi via telepon, lalu bagian penjualan mengirim invoice kepada konsumen. Konsumen melakukan pembayaran melalui transfer uang ke bank yang ditunjuk (sesuai invoice), selanjutnya melakukan konfirmasi kepada bagian penjualan bahwa telah melakukan pembayaran dengan mengirim bukti transfer. Lalu bagian penjualan melakukan pengecekan terhadap rekening bank, jika pembayaran telah diterima maka bagian penjualan mengirimkan copy invoice dan bukti transfer kepada bagian accounting untuk dibuatkan kwitansi. Setelah itu bagian penjualan mengirim Kwitansi dan surat jalan kepada bagian inventory, bagian inventory menyiapkan barang lalu mengirim kepada kurir pengiriman, bagian inventory mendapatkan resi pengiriman dan melakukan cek terhadap pengiriman tersebut. Setelah barang diterima Konsumen maka bagian inventory memberikan konfirmasi kepada bagian penjualan. Bagian Penjualan merekap nilai penjualan pada Daily Sales Report yang dikirim kepada Administrative Manager. Setiap akhir periode Bagian Penjualan membuat Monthly Sales 
Report (Laporan Penjualan Bulanan) laporan tersebut diserahkan kepada Administrative Manager.

\subsection{Activity Diagram}

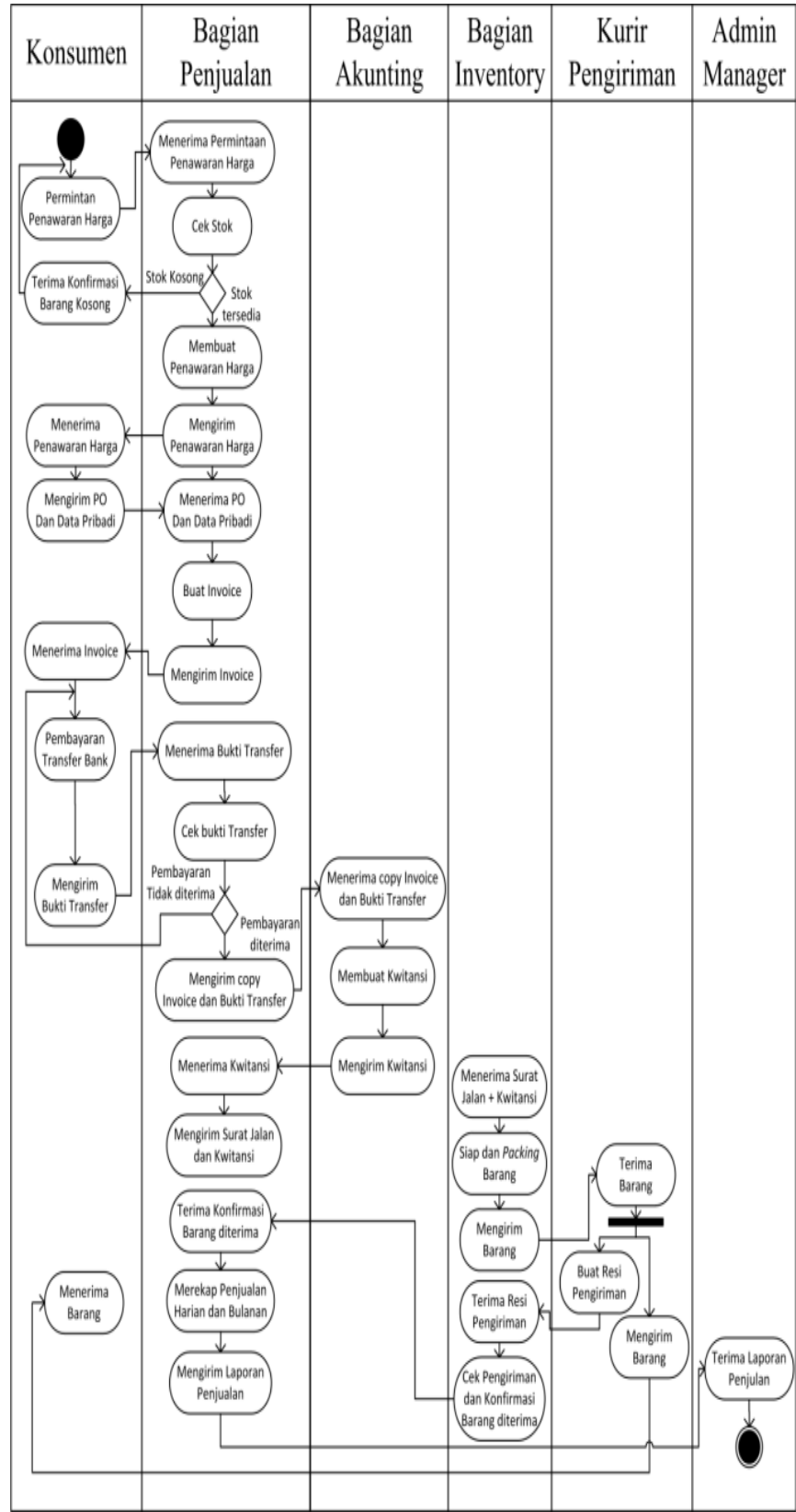

Gambar 1. Activity Diagram Sistem Berjalan

\subsection{Use Case Sistem Usulan}

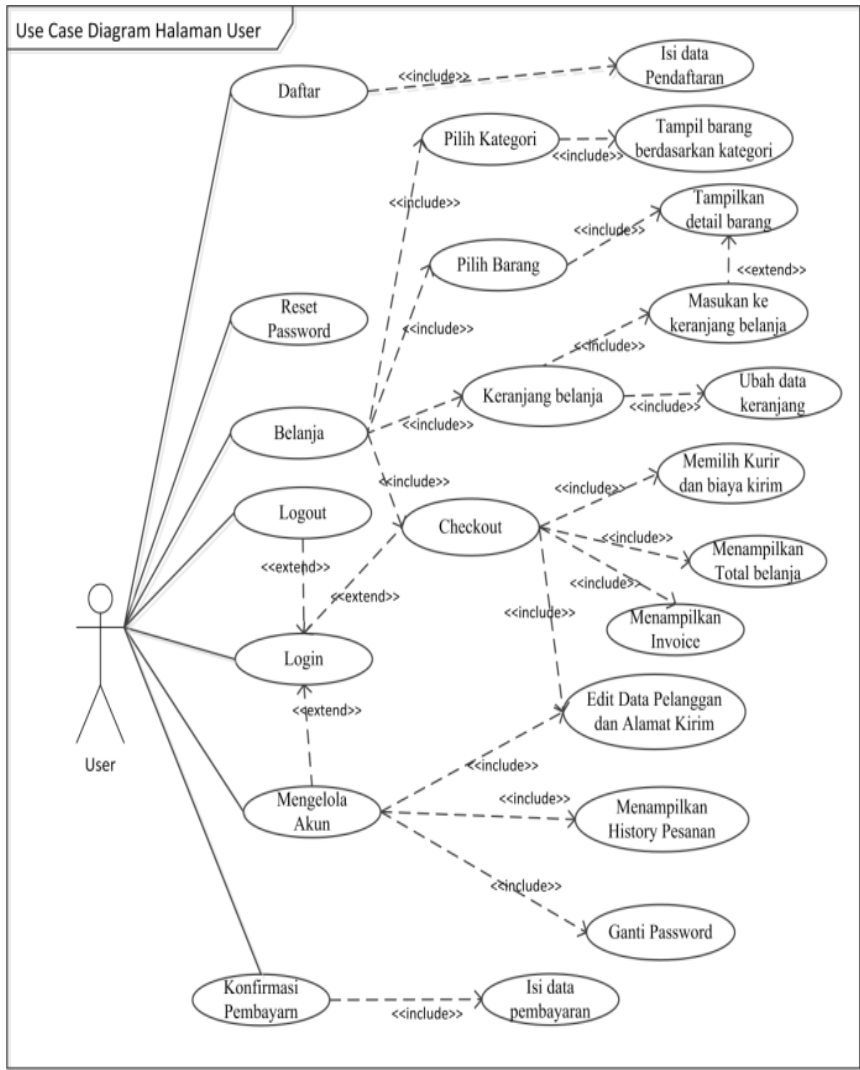

Gambar 2. Use Case Diagram E-Commerce

Tabel 1. Deskripsi Use Case Belanja

\begin{tabular}{|c|c|}
\hline Use Case Name & Belanja \\
\hline Requirements & A1 - A8 \\
\hline Goal & $\begin{array}{l}\text { User dapat melakukan pembelian } \\
\text { secara online }\end{array}$ \\
\hline Pre-conditions & User melihat katalog produk \\
\hline Post-conditions & $\begin{array}{l}\text { Sistem mengirimkan rincian } \\
\text { belanja (invoice) melalui e-mail }\end{array}$ \\
\hline $\begin{array}{ll}\begin{array}{l}\text { Failed } \\
\text { condition }\end{array} & \text { end } \\
\end{array}$ & $\begin{array}{l}\text { User membatalkan proses belanja } \\
\text { online }\end{array}$ \\
\hline Primary Actors & User \\
\hline $\begin{array}{l}\text { Main Flow/Basic } \\
\text { Path }\end{array}$ & $\begin{array}{l}\text { 1. User memilih produk dan } \\
\text { menambahkan ke keranjang } \\
\text { belanja } \\
\text { 2. User memilih tombol "lanjut } \\
\text { ke pembayaran" pada } \\
\text { halaman keranjang belanja. } \\
\text { 3. Sistem menampilkan rincian } \\
\text { belanja. } \\
\text { 4. Sistem menampilkan data } \\
\text { pengiriman } \\
\text { 5. User merubah alamat } \\
\text { pengiriman. } \\
\text { 6. Sistem menampilkan pilihan } \\
\text { jasa pengiriman dan biaya } \\
\text { kirim. } \\
\text { 1. User memilih pilihan jasa } \\
\text { pengiriman dan biaya kirim. }\end{array}$ \\
\hline
\end{tabular}




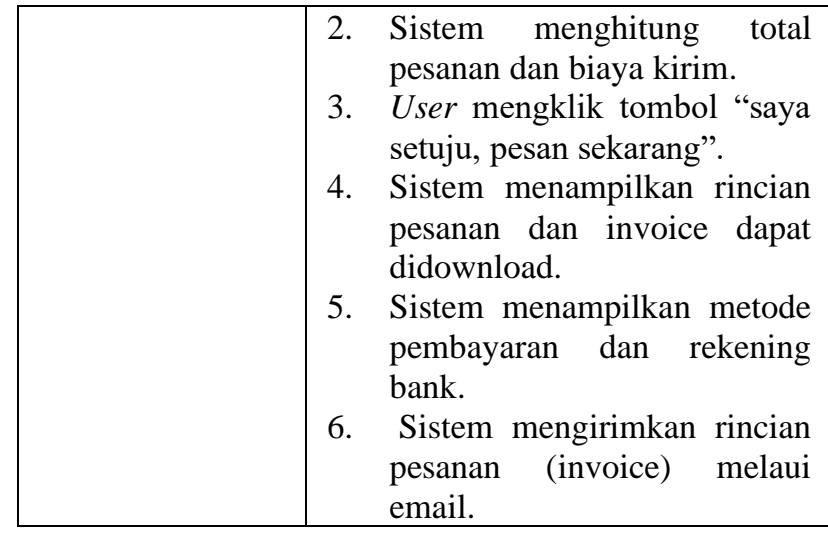

\subsection{Desain Database}

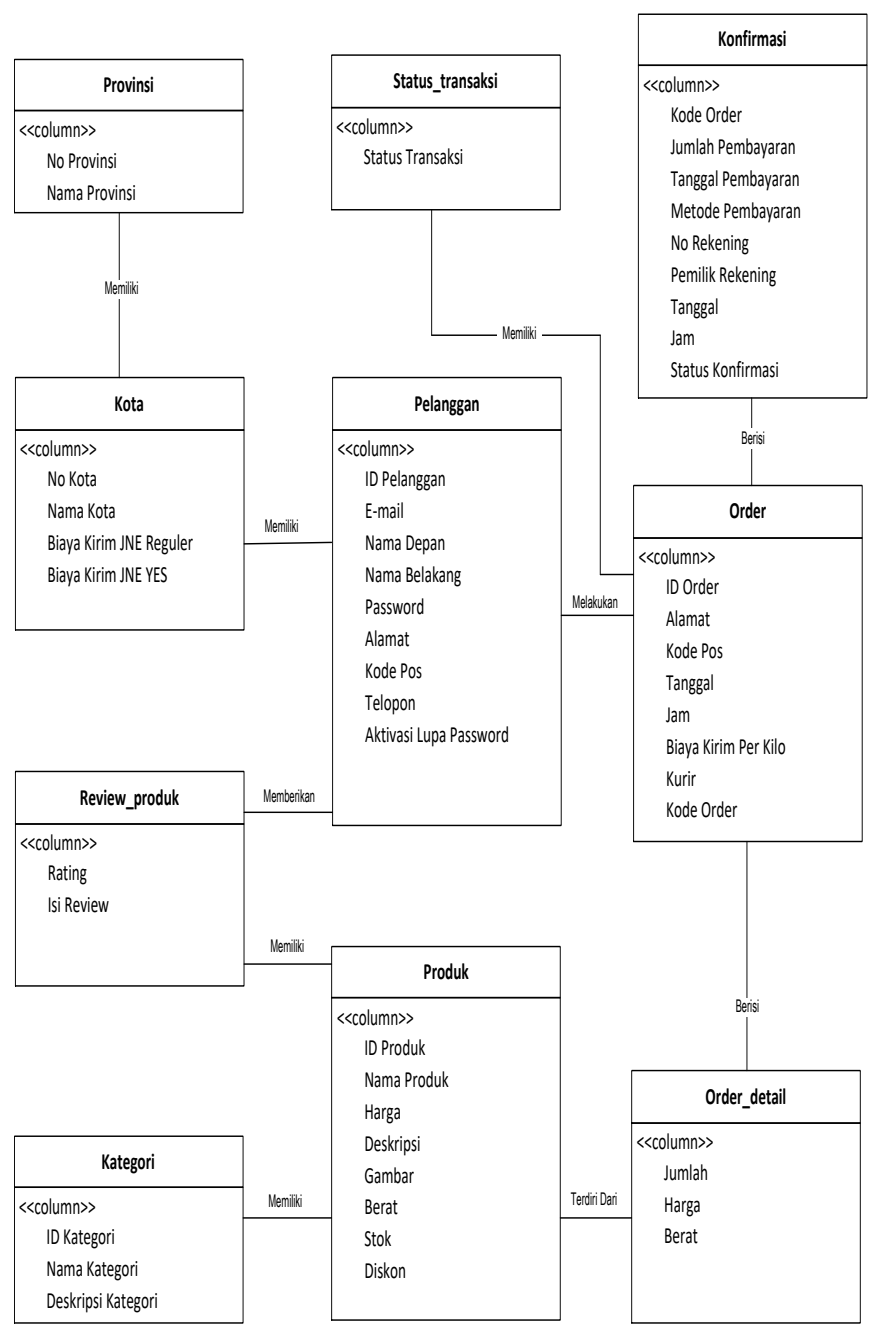

\subsection{Class Diagram}

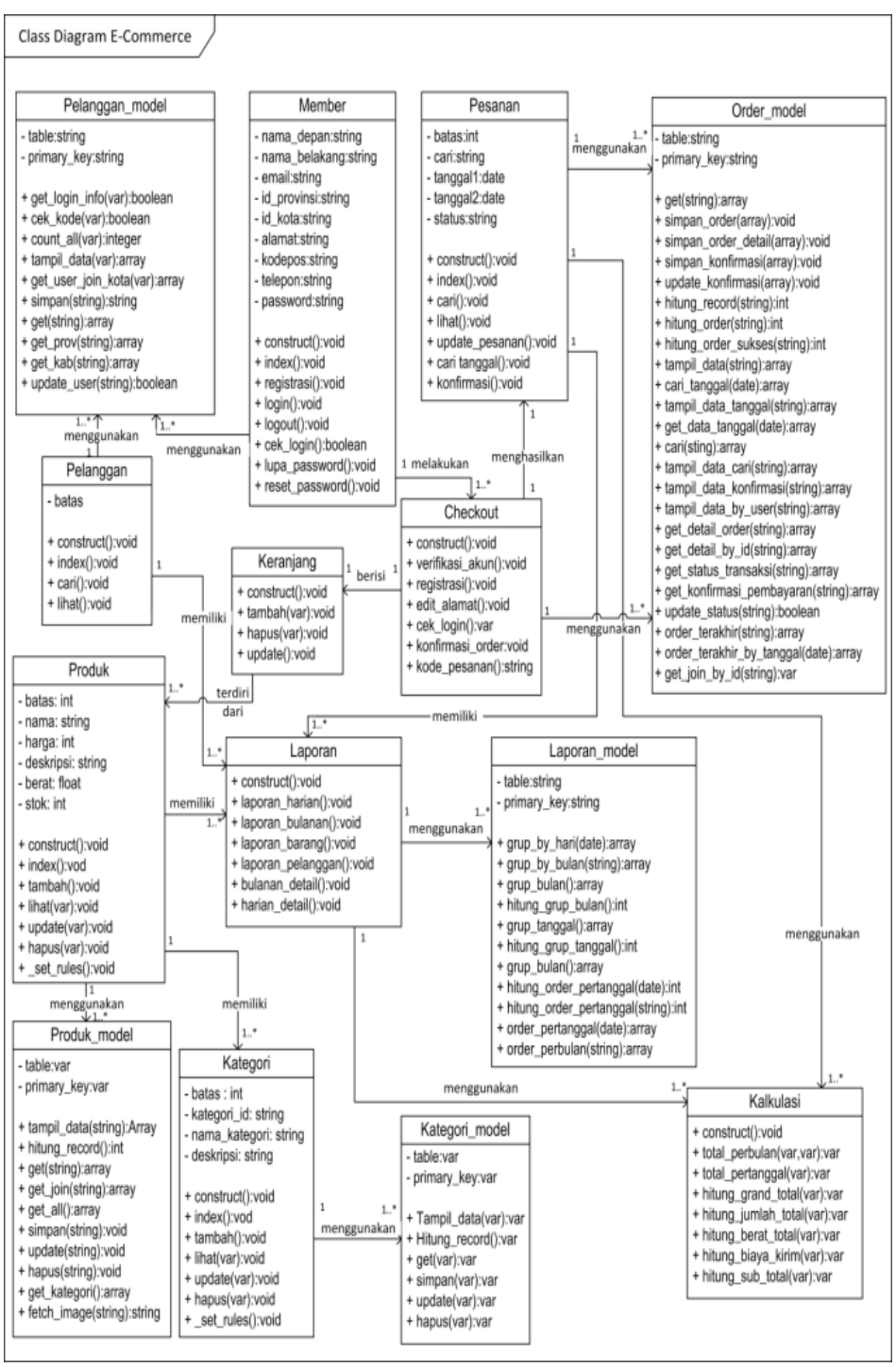

Gambar 4. Class Diagram E-Commerce

Gambar 3. Desain Logical Data Model 


\subsection{Sequence Diagram}

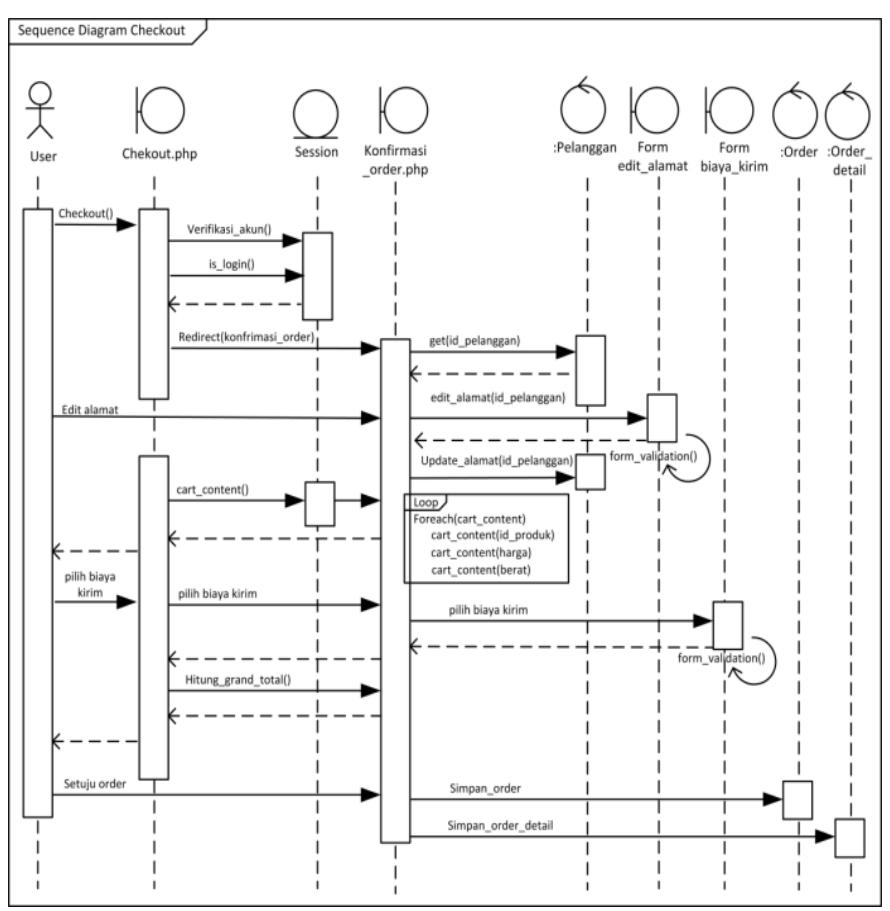

Gambar 5. Sequence Diagram Checkout

\subsection{Component Diagram Fungsi}

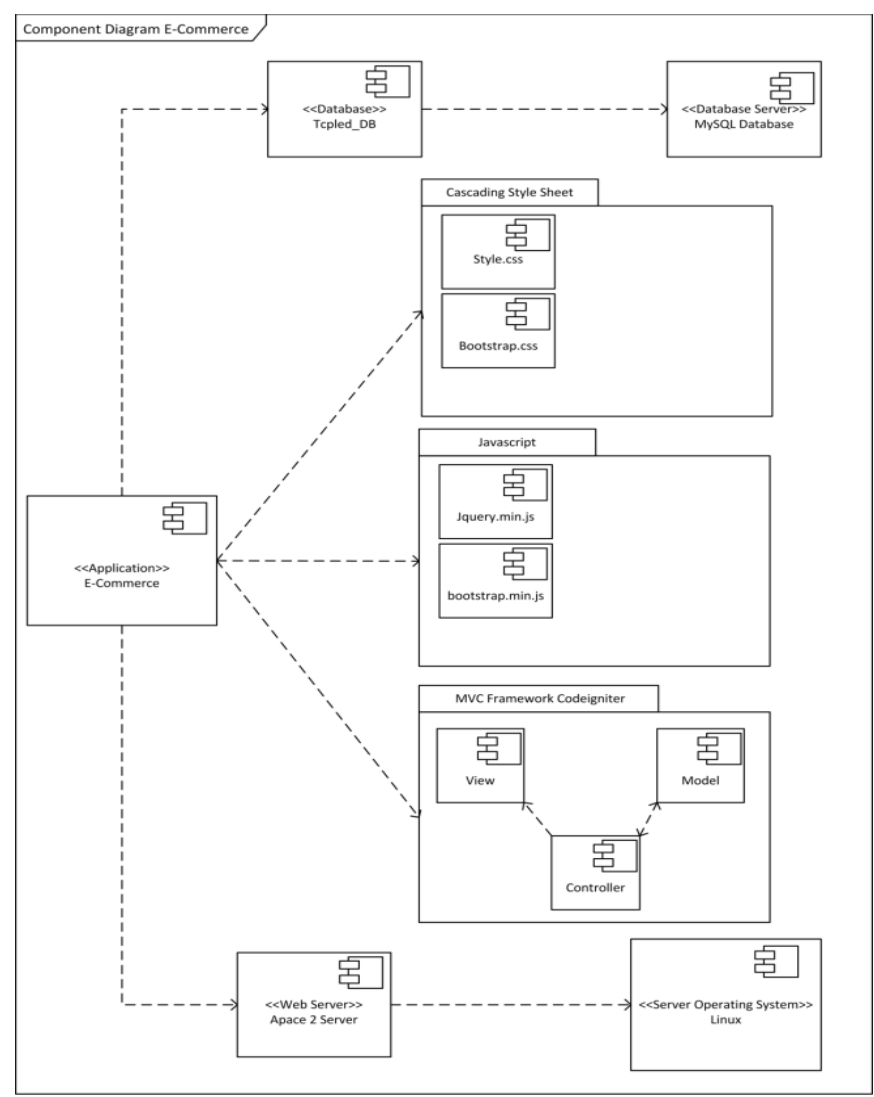

Gambar 6. Component Diagram E-Commerce
4.8. Deployment Diagram

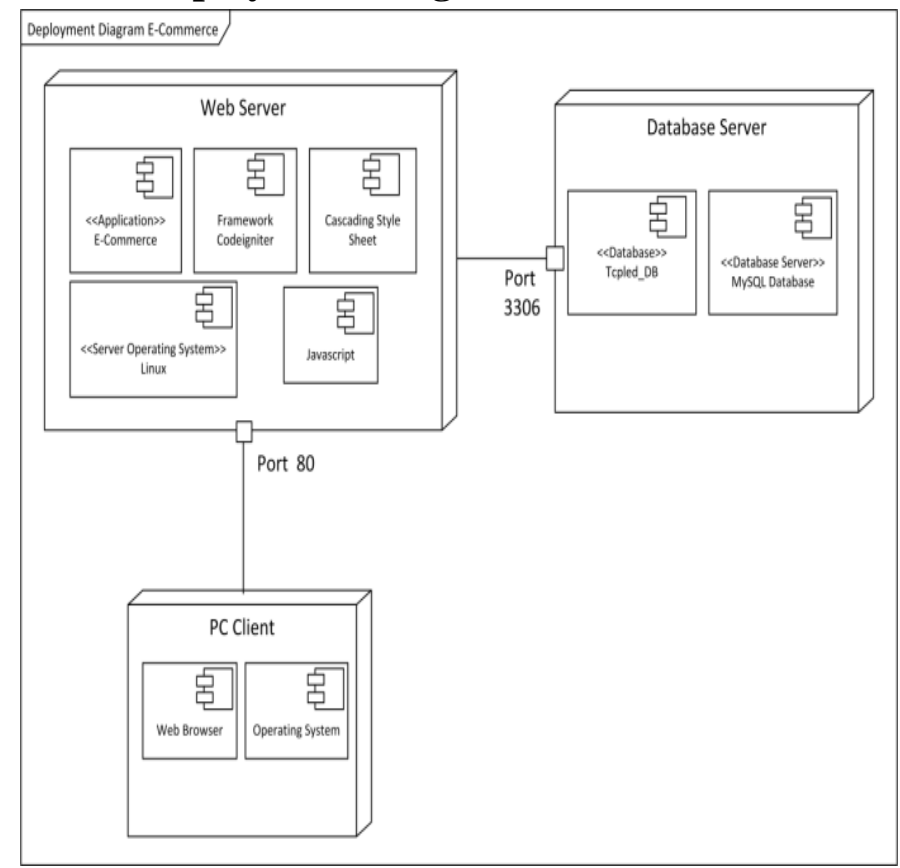

Gambar 7. Component Diagram E-Commerce

\subsection{Spesifikasi Sistem Dokumen Usulan}

$\begin{array}{ll}\text { Nama Dokumen } & \text { : Laporan Penjualan Bulanan } \\ \text { Fungsi } & \text { : Merekap data penjualan } \\ & \text { perbulan. } \\ \text { Sumber } & : \text { Administrator } \\ \text { Tujuan } & : \text { Administrative Manager } \\ \text { Media } & : \text { Tampilan } \\ \text { periode. } & \text { : Setiap Bulan pada akhir } \\ \text { Format } & \text { : Lampiran B-3 }\end{array}$

\subsection{Tampilan Program}

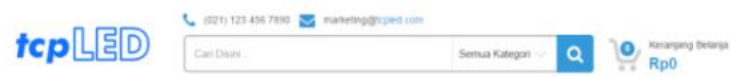

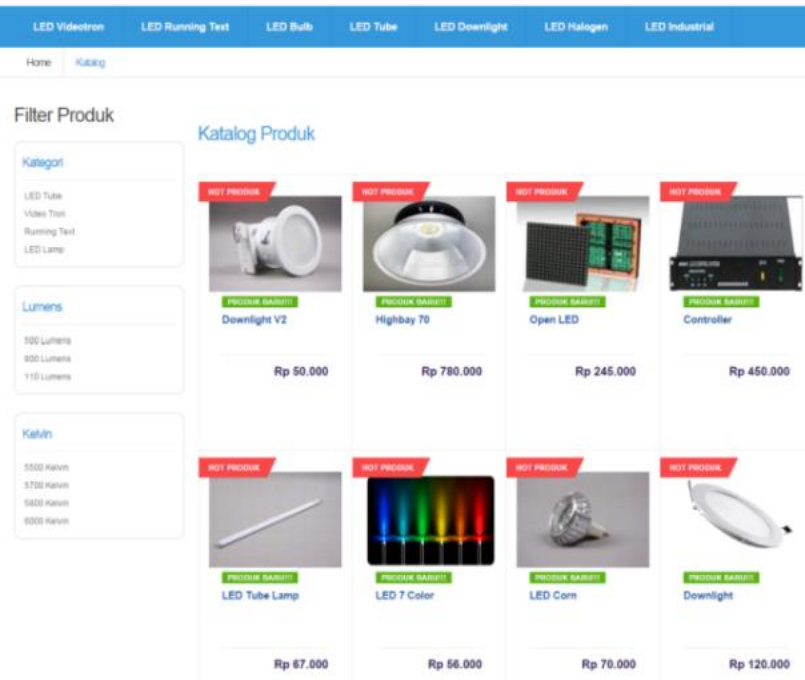

Gambar 8. Katalog Produk 
Keraniang Belanja

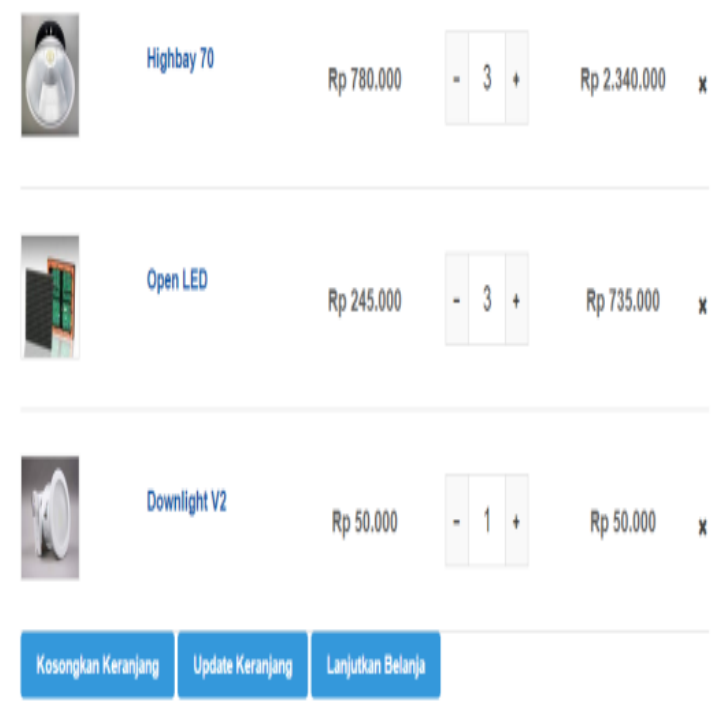

Gambar 9. Keranjang Belanja

\section{KESIMPULAN}

Berdasarkan analisa yang telah dilakukan, maka Perancangan E-Commerce pada PT. Adtronic Indonesia memiliki kesimpulan sebagai berikut:

1. Dengan adaanya sistem E-Commerce PT. Adtronic Indonesia dapat mengelola transaksi penjualan secara otomatis dan sederhanana.

2. Pihak manajemen dapat mengontrol dan melakukan pengecekan secara langsung terhadap penjualan perusahaan.

3. Sistem belum terintegrasi dengan bank, sehingga harus melakukan pengecekan manual untuk mengetahui pembayaran telah ditransfer atau belum.

4. E-Commerce memperkecil kesalahan dalam pembuatan laporan penjualan.

5. Membantu pelanggan dalam mendapatkan informasi produk, tanpa harus menghubungi layanan pelanggan.

Untuk meningkatkan kinerja $E$ Commerce pada PT. Adtronic Indonesia penulis mengusulkan beberapa saran sebagai berikut:

1. Perlu adanya sistem yang terintegrasi langsung dengan bank (Bank Payment Gateway).
2. Melakukan penghapusan data yang tidak terpakai untuk mempercepat kinerja sistem.

3. Selalu melakukan update produk jika terjadi perubahan sehingga memudahkan pelanggan untuk mendapatkan informasi produk.

4. Melakukan Backup data secara rutin untuk menghindari sistem crash atau file corupt.

\section{DAFTAR PUSTAKA}

[1] Budiharto, Widodo. 2013. Web Programming membangun aplikasi web handal dengan J2EE dan MVC. Yogyakarta:Andi.

[2] Doyle, Matt. 2010. Beginning PHP 5.3. Indiana: Wiley Publishing.

[3] Galih, Sinta Tridian, Mustafid dan Aris Sugiarto. 2011. Rancang Bangun Portal E-Commerce Semarang-Handycraft Berorientasi Objek. ISSN: 2088-3587. Semarang: Jurnal Sistem Informasi Bisnis Vol. 1 No. 1 April 2011:16-21 diambil dari http://ejournal.undip.ac.id/index.php/jsin bis/.(2-November-2014)

[4] Handita, Ditya Banu, Umar dan Umi Fadlillah. 2012. Sistem Informasi Penjualan Berbasis Web pada Usantek. ISSN: 1411-8890. Surakarta: Jurnal Emitor Vol. 12. No. 01 Maret 2012: 2633.

[5] Jogiyanto, HM. 2005. Analisa dan Disain Sistem Informasi Terstruktur. Yogyakarta: Andi.

[6] Kotler, Philip dan Gary Armstrong. 2010. Principles of Marketing. Edisi ke13. Prentice Hall: Pearson.

[7] Nugroho, Adi. 2006. e-Commerce. Memahami Perdagangan Modern di Dunia Maya. Informatika :Bandung. 
[8] Nugroho, Adi. 2010. Rekayasa Perangkat Lunak Berorientasi Objek dengan Metode USDP. Yogyakarta: Andi.

[9] Pressman, Roger S. 2010. Software Engineering A Practitioner's Approach Seventh Edition. New York : McGrawHill Companies.

[10]Sakur, Stendy B. 2010. PHP 5 Pemrograman Berorientasi Objek Konsep dan Implementasi. Yogyakarta : Andi.

[11]Sidik, Betha. 2012. Framework CodeIgniter. Bandung: Informatika.

[12] Simamarta, Janner dan Iman Prayudi. 2006. Basisdata.Yogyakarta:Andi.

[13] Sitorus, Moris Chandra. 2014. Sistem Informasi Penjualan Buku Berbasis Web Menggunakan Model View Controller (MVC) Studi Kasus Toko Buku Naga Timbul Pakam. ISSN: 2301-9425. Medan: Jurnal Pelita Informatika Budi Darma Vol. VII, No. 2 Agustus 2014:153-156.

[14]Sukamto, Rosa Ariani dan M. Shalahudin. 2013. Rekayasa Perangkat Lunak. Bandung: Informatika.

[15] Widodo, Prabowo Pudjo, dan Herlawati. 2011. Menggunakan UML. Bandung: Informatika. 